\title{
Attitude to Business Reality, Perceived Value Creation and Subjective Norms: How They Impact on Students of Higher Learning Institutions' Self-Employment Intentions in Malaysia
}

\author{
Mudashir Gafar \\ Wan Fauziah Wan Yusoff \\ Rozilah Kasim \\ David Martin
}

\begin{abstract}
Faculty of Technology Management and Business, Universiti Tun Hussein Onn Malaysia, 86400 Parit Raja Batu Pahat Johor Malaysia; gafarmudashir@yahoo.com, fauziahy@uthm.edu.my, rozilah@uthm.edu.my and martin@uthm.edu.my
\end{abstract}

Doi:10.5901/mjss.2015.v6n5s1p186

\begin{abstract}
The modern-day economy demands dynamic real estate entrepreneurial professionals as graduates' job placement are becoming more competitive. The purpose of introducing entrepreneurship education into the Malaysian Higher Learning Institutions (HLIS) is to boost the employability of the graduates but the realization of this purpose in some of the university's programmes is still unclear. In this regard, this research employed the theory of planned behaviour to assess hypotheses of the role of attitude in business reality, perceived value creation perceptions and subjective norms in influencing the selfemployment intention of real estate management (REM) students. The hypotheses were tested using cross-sectional data from 408 REM students of the Malaysian public universities. The research findings reaffirmed that attitude to business reality and perceived value creation did play a significant role in explaining REM students' self-employment intention while subjective norms had no significant impact. However, the role of attitude to behaviour in business reality acted to be more relevant. The implications of the research findings could impact educational policy, particularly, academic entrepreneurship education.
\end{abstract}

Keywords: Entrepreneurship education, Theory of planned behaviour, Self-employment intention, Structural equation modeling

\section{Introduction}

In recent time, competition for employment among graduates of higher learning institutions (HLIs) has been growing. The current economic recession is also compounding the issue of graduates' unemployment in both developed and developing nations, in fact, Malaysia is no exception. The mounting pressure of the graduates' job competitiveness or unemployment is creating lots of concerns both for the Malaysian government and general public; particularly it could create more social problems. Government policymakers and renowned scholar have suggested entrepreneurship by way of self-employment as one of the most effective alternates to graduates' unemployment. More so, self-employment can contribute substantially to national economic development.

The principal proponents of this study recognize the progression of the entrepreneurial university over the mainstream university for the real creation of the modern-age economy. Hence, Blenker et al. (2011) and Fayolle (2013) acknowledged exponential growing of literature in the academic entrepreneurship with little empirical support. Likewise, entrepreneurship research in the domain of Real Estate Management (REM) is even far less (Poon, 2013; Gafar et al., 2013). Even though, Poon and Brownlow (2015) and Gafar et al. (2014a) argued for the paradigm shift to the REM education towards a more entrepreneurship orientation. In the present competitive job market, the culture of entrepreneurship; commercial awareness; entrepreneurial creativity and innovation open more employment opportunities for the practicing real estate surveyors. Moreover, it is well said that a career that inclined by the entrepreneurship provide the individuals with excellent opportunities to enjoy self-fulfilment, independence, and financial freedom/gain. Much more, it added value creation by way of innovation, career enrichment and economic growth of the nation.

In this regard, this research employed validated theory of planned behaviour (TPB) developed by Ajzen to assess the role of attitude to business reality, perceived value creation perceptions and subjective norms on the REM students' self-employment intention after their participation in the university's entrepreneurship education program. However, few studies were available on how the perception of self-employment is formed in a discipline-based entrepreneurship program, in particular, REM. Hence, it is debatable that social norms regarding entrepreneurship, REM students' attitude 
to business reality and perceived value creation would impact their intention toward self-employment.

Therefore, the aim of this research is to test the existence and effect of the three components of the cognitive model. The study employ quantitative research approach with cross-sectional large sample size from four Malaysian public universities and the essence is for the generalization of the research findings. The data collected from 408 students of REM were used for the empirical analysis. The formulated research hypotheses were tested using structural equations modelling (SEM).

The essence of this investigation is to fulfil one of the priorities of the Malaysian government to assess the performance of the entrepreneurship education in the HLIs. Also, the research is to provide further understanding on which of the cognitive constructs more predict the REM students' self-employment intention. Consequently, the findings are to reveal the entrepreneurship authenticity before graduation. The connotation of the results would provide implication for both theoretical and empirical contributions in the domain of entrepreneurship process in the educational program.

\section{Theoretical Foundation}

Entrepreneurship process in regards to self-employment intention is acknowledged to be a function of attitude to behaviour, perceived behaviour control and subjective norms (Ajzen, 2002). Notable scholars have provided diverse research outcomes in different geographical setting. As this paper is focussed on the Malaysian environment with emphasises on REM students, the literature given below fit into these essential functions.

However, entrepreneurship as a cognitive process is widely supported in the literature. Notable scholars have acknowledged individual's intention to be self-employed as a complex and intricate mental process (Nabi et al., 2006). Krueger et al., (2000) employed Ajzen's (1991) the theory of planned behavior to provide theoretical and empirical understanding of the mental process for individual's self-employment intention to business/firm creation. In the same perspective, several other scholars have acknowledged the usefulness of this theory to elucidate the business start-up decision (Kolvereid\&lsaksen, 2006; Fayolle et al., 2006). Therefore, individual's intention to self-employed depend on his/her attitude to behaviour, perceived behaviour control over the business start-up and perceived subjective norms to become (or not) an entrepreneur.

Therefore, this research holds on to the cognitive approach in conjunction with the use of entrepreneurial intention model. Though, several studies have been published in this area. Nevertheless, more empirical studies are still required to create an in-depth understanding of what the factors affecting self-employment intention are, particularly among the REM students in Malaysian public universities.

Moreover, there is still much to be known regarding the way in which REM students' perceptions are formed (Zamberi Ahmad, et al., 2014). Even though, Poon (2012) and Poon and Brownlow (2015) stated that REM education is inherently entrepreneurial in nature. Some commentators have argued that societal values, attitude to business and perceived business capacities about entrepreneurship will influence the motivational antecedents of self-employment intention (Ernest et al., 2015). In fact, Linan (2009) stated that individual's closer environment is a predictor of entrepreneurial activity, and the belief was that such person will experience more inclination towards entrepreneurship as a career preference. Likewise, an individual's perceived behaviour or inherent skills and competencies (entrepreneurial capacities) could also influence his/her entrepreneurial intention (Gafar et al., 2014). Therefore, it is apparent that individuals' intrinsic entrepreneurial capacities connote perceived behavioral control. In another word, students who are feeling they have a higher level of individual entrepreneurial capabilities will likewise have positive believe they can establish a business venture/firm after graduation. Besides, it might be argued that a high self-perception regarding entrepreneurial value creation capacities would also command more favourable attitudes toward business reality.

Therefore, it is of paramount interest in this study to test whether attitude toward business reality, perceived value creation and subjective norms have any significant impact on the REM students' self-employment intention. Particularly now that graduates' job competitiveness is on the increase that made the Malaysian government to emphasized in the entrepreneurship teaching as an agent of transformation and for the accomplishment of the vision 2020.

However, it is expected that a judgment of entrepreneurship in the individuals' society would impact on personal attitude and subjective norms. That is, when the society around students is supportive of entrepreneurship, they would feel more inclined towards entrepreneurship, and would feel their closer environment and the government approves their decision to become entrepreneurs. On the other hand, entrepreneurial skills would have its primary effect on perceived behavioural control (a concept quite close to perceived value creation or self-efficacy), but may also affect attitudes to behaviour and subjective norms.

In general, individuals' behaviour have been explained by the theory of planned behaviour, in fact, entrepreneurship scholars have adopted it in several studies. Fayolle et al. (2006) empirical study have shown that most 
of what every individual deem to be entrepreneurship essentially is premeditated planned behaviour. Hence, expected outcome of individuals' intentions are for the firms creation (Gafar et al., 2013). Also, progression into self-employment is an action that is foretold by intentions (Thompson \&Kwong, 2014).

Furthermore, Bae, et al. (2014) and Fayolle, et al. (2014b) reaffirmed that individual's family business background, entrepreneurial working experience and gender do in some way impact self-employment/entrepreneurial intentions through their effect on attitude, perceived behavioural control and subjective norm.

Krueger (2009) asserted that the fundamental construct of intentions emerged to be profoundly essential to human decision-making and, as such, it should provide multidirectional approach to explore and explain the connection between intention and vast array of dynamic factors that relate to decision making under creativity/innovation skills, business/management competence and risk taking proficiency. This statement provides the opportunities for the formulation of an integrative theoretical model of the entrepreneurial process that is linking core objectives of entrepreneurship teaching (business reality and value creation capacities) and intention models.

Finally, at the methodological perspective, Fayolle and Linan (2014) and Fayolle et al. (2006) reaffirmed the need to promote more empirical studies using homogeneous samples of future entrepreneurs, in particular, students of HLIs with a purpose to identify causal order in the entrepreneurial process. In fact, researchers' recent publication on entrepreneurship suggested the use of multi-method research approach in conjunction with second order statistical tools (SEM) to vindicate their research findings.

\subsection{Formulation of Research Hypotheses}

Every graduating student is faced with two to three employment options after graduation, which is either to be employed in an organisation or self-employed (Douglas \& Shepherd, 2002). More so, this is an occupational decision process, and students of HLIs are always preoccupying with the employment decision whether to enter a paid job or become selfemployed. The economy uncertainty that created graduates' job competitiveness might be contributing to the emergence of the third employment alternative. An instance is where the graduating students may opt to work surely in a part-time operation or partners in a business venture combine with a paying job so as to augments their incomes. Here, selfemployment is considered as a continuous construct by measuring the degree of feasibility and desirability of REM students' willingness to consider self-employment as a career option either in the capacity of employment option two or three.

It was apparent in the literature that there is a general acceptance among scholars that attitude toward a subject matter is determined by beliefs about that matter (Ajzen, 1991), whereas, the matter at hand is self-employment. More so, prior studies have identified some key factors for entrepreneurs to embark on venture creation.

In accordance to Kolvereid (2006), an empirical study on the students of HLIs showed that attitude, perceived behavioural control and subjective norm were significant predictors of their intentions to pursue a self-employed career. With the same variables construct, Tkashev and Kolvereid (1999) also reaffirmed that research findings on the students from different tertiary institutions and fields of studies indicated that perceived behavioural control was a strongest predictor of self-employment intention followed by attitude and subjective norm respectively. These research works also recorded that student having enterprise experience only in some way impacted entrepreneurial intentions through their influence on attitude, perceived behavioural control and subjective norm.

In this research, entrepreneurship self-employment intention model is formulated to understand the influence of attitude to business reality, perceived value creation and subjective norms in determining self-employment intentions. Based on the theory of planned behaviour approach (Ajzen, 1991), it could be argued that REM students take their decision to be self-employed after graduation based on three foundational and motivational factors: (1) their inherent business knowledge in the capacity toward business reality and as an attitudinal attraction towards entrepreneurship (Gafar et al., 2014a), their perceived behavioural control in the capacity of value creation know-how (Van Gelderen et al., 2008), and the perceived subjective norms (Linan \& Chen, 2009).

On account of the given literature, first research hypothesis can be derived as:

H1: Attitude to business reality has a positive impact on the REM students' self-employment intention.

In addition, attitude towards business reality refers to the attractiveness or degree to which the individual holds positive or negative business know-how about being an entrepreneur (Ajzen 1991, 2002; Kolvereid 1996). In this regards, student willingness is an important element concerning the perception of desirability that affects entrepreneurial/selfemployment intention. The second motivational factor is perceived behavioural control or self-efficacy; that is, the perceived easiness or difficulty to value creation by way of venture creation in the capacity of becoming an entrepreneur (Ajzen, 1991). The significance of this variable in the self-employment intention that leads to new-firm creation process 
resides in its predictive capacity. Hence, it reveals the perception that the student will be able to control that behaviour (Wilson et al., 2007; Ajzen, 2001). In this line, this motivational component could be influenced by different processes, such as creativity and innovation skills, competence mastery and role modelling. Subjective norms connote socialeconomic influences on the students' intention to be self-employed after graduation (Zhao et al., 2005).

However, the construct of perception of venture desirability in the Shapero's entrepreneurial event model (1982) connotes Ajzen's determinants of attitude towards the behaviour and this could be best explain within the context of students' attitude to business reality and personal attraction. Hence, perception of venture feasibility, as proposed by Shapero, is analogous to Azjen's perceived behavioural control (Krueger et al., 2000) or to the idea of perceived selfefficacy and this could also be explicated as students' perceived value creation capacity (Gafar et al., 2014b). Nevertheless, both Shapero's and Ajzen's entrepreneurial intention models have been widely used to study entrepreneurial self-employment intention and suitability of the theory of planned behaviour have been more dependable in the past research studies (Van Gelderen et al., 2008; Fayolle \& Linan, 2014a).

In respect to the given literature, second research hypothesis formulated as:

H2: Perceived value creation has a positive impact on the REM students' self-employment intention.

Consequently, perceived social value and pressure from pier friends and family members or other personality in the society noted as subjective norms (Ajzen 2002; 1991) which influence individual's intention towards entrepreneurship. At the same time, the societal values (subjective norms) have tendency to impact more strongly or weakly on selfemployment intention (Fayolle et al., 2006) for individuals with strong or weak internal locus of control (Ajzen, 2002; 2001). More so, several studies in the entrepreneurship literature established that there is no significant impact or direct relationship between subjective norms and self-employment intention (Linan \& Fayolle, 2015; Linan et al., 2011; Fayolle et al., 2006; Kolvereid \& Isaksen, 2006; Ismail et al., 2009).

On the basis of above-given literature, the third research hypothesis formulated as:

H3: Perception of subjective norms has a positive impact on the REM students' intention to be self-employed.

Therefore, the entire research constructs relationships employed Ajzen's entrepreneurial intention model and proposed the research assessment model as illustrated in Fig. 1.

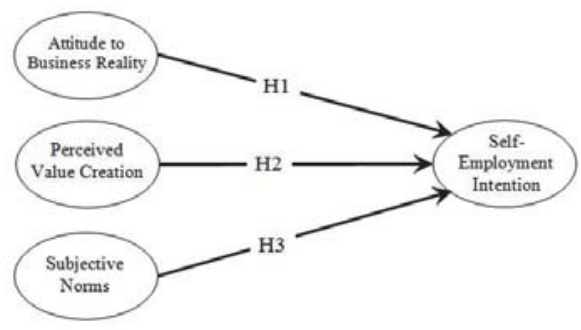

Figure 1: Hypothesised Research Assessment Model

\section{Research Methodology}

The research employed mainly quantitative research approach because of large sample size and for the generalization of the research findings. The respondents target were the real estate management (REM) students who currently participated in a compulsory entrepreneurship education program in their second-year field of study. Data collected from a sample of 480 REM students in the Malaysian public universities through a purposive sampling method that is often used in entrepreneurship research (Fayolle et al., 2006; Matlay, 2008). The four public universities were Universiti Malaya (UM), Universiti Teknologi Malaysia (UTM), Universiti Teknologi Mara (UiTM) and Universiti Tun Hussien Onn Malaysia (UTHM). A total of 437 questionnaires were returned, and 29 of the questionnaires were not adequately filled. Therefore, only 408 students' responses were use for the statistical analysis.

However, the scales of measurement for the constructs: attitude to business reality, perceived value creation and subjective norms were adapted from a statistically robust and theoretically sound questionnaire developed by Linan and Chen (2009), Krueger (2000; 2009) and Kolvereid and Isaksen (2006). Besides, validated items of measurement for the self-employment construct were adopted from Fayolle et al. (2006).

Statistical package for social sciences (SPSS) version 22 and Structural equation modeling (SEM) were used to analysis the data collected. The present of structural relationships between the entire research constructs was examined. The reason was that majority of past studies on self-employment intention commonly used simple or multiple regression 
models even with the possibility of biased outcome (Linan \& Chen, 2009; Guerrero et al., 2008).

However, more researchers have shown that the application of SEM could provide a better understanding of interrelationship impact of the constructs in the research model (Kline, 2011; Guerrero et al., 2008). Particularly, most of the past entrepreneurship empirical outcomes on the effect of subjective norms in the theory of planned behaviour are still ambiguous. In fact, it was omitted by some scholars (Shapero \& Sokol, 1982; Peterman \& Kennedy, 2003) and other pronounced it insignificant (Souitaris e al., 2007; Fayolle et al., 2006), whereas in reality, it is a factor of substantial impact in every individual decision making that is self-employment intention to behaviour.

In SEM analysis, acceptance of any structural research model is assessed based on the use of several goodnessof-fit indexes (Awang, 2014). Hence, chi sq (X2) test, ratio of X2 to its degree of freedom (X2/df) were computed and a value of not more than 5.0 was employed as an indicative of an acceptable fitness for the hypothesized research model and the sample data at hand (Hair et al., 2011). Consequently, other fit indices are also considered to establish the fitness of the research model which were Root Mean Square Error of Approximation (RMSEA), Goodness-of-Fit Index (GFI) were employed as measure of absolute fit and the Tucker-Lewix Index (TLI) and Comparative Fit Index (CFI) as indices of incremental fit. In the literature review, Awang (2014) and Hair et al. (2011) recommended value of 0.90 or more for the $\mathrm{GFI}, \mathrm{CFI}$ and $\mathrm{TLI}$, whereas, value of 0.08 or less is set for REMSEA as a good fit.

\section{Research Findings}

Prior to the process of data analysis, the data collected from the cross-sectional REM students were coded and analyzed with the statistical package for social science (SPSS) version 22. Data screening processes, normality and reliability of the data evaluated, and results presented in Table 1.1. Prior to factor analyses, the Mahalanobis distance was computed to identify any possible outlier cases and no significant outliers observed. As earlier mentioned, out of 480 questionnaires distributed a total of 437 questionnaires were returned (91\%), and 29 of the returned questionnaires were not adequately filled. Therefore, valid responses of 408 students (85\%) were used for the empirical analysis. The descriptive analysis of the valid sample in term of gender sex ratio is 79.8 percent (female) and 20.2 percent (male). The ethnicity distributions were Malay (63.91\%), Chinese (32.99\%), and Indian (3.1\%) respectively.

Hence, the result showed that the mean values for each main construct (ABR, PVC, SN and SEI) were within the range of 2.67 to 3.29 (see Table 1.1). At the same time, normality assumption for this research must not be violated because maximum likelihood estimation measures were employed for this research (Awang, 2014; Hair et al., 2011). In Table 1.1, the computation values of skewness and kurtosis were within the normality parameters of -1 to +1 (Pallant, 2011), and this showed that the data collected presented a normal distribution.

In addition, the constructs' reliability test was examined through items' reliability and composite reliability. As shown in Table 1.1, the Cronbach alpha were above 0.7, and inter-item total correlation were positive and the majority of the values were greater than 0.3 , therefore, acceptable (Pallant, 2011).

Subsequently, the principal component factor analysis for entire research constructs' items were examined and all presented strong factor loading above 0.3. According to Awang (2014) and Hair et al. (2011) the entire 32 items were satisfactory (see Table 1.2) and then considered for the inference statistical analysis that is confirmatory factor analysis (CFA) and structural equation modeling (SEM).

Table 1.1: Measure of Reliability and Normality

\begin{tabular}{|c|c|c|c|c|c|c|c|}
\hline Constructs & Item & Mean & SD & Item-Total Correlation & Cronbach Alpha & Skewness & Kurtosis \\
\hline \multirow{8}{*}{ 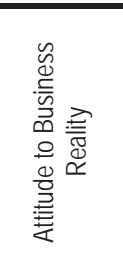 } & ABR1 & 2.93 & .838 & .639 & \multirow{8}{*}{0.821} & .029 & -.389 \\
\hline & ABR2 & 3.15 & .760 & .559 & & .185 & -.051 \\
\hline & ABR3 & 2.90 & .909 & .719 & & .215 & -.308 \\
\hline & ABR4 & 3.00 & .837 & .553 & & -.131 & .320 \\
\hline & ABR5 & 2.97 & .839 & .348 & & .135 & -.782 \\
\hline & ABR6 & 3.00 & .796 & .647 & & -.079 & -.008 \\
\hline & ABR7 & 2.87 & .779 & .685 & & -.079 & -.392 \\
\hline & ABR8 & 3.06 & .898 & .239 & & .058 & -.380 \\
\hline \multirow{5}{*}{ 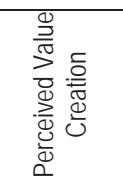 } & PVC1 & 2.83 & 954 & .793 & \multirow{5}{*}{.877} & .236 & -162 \\
\hline & PVC2 & 2.77 & .862 & .327 & & .116 & -.084 \\
\hline & PVC3 & 2.76 & .905 & .647 & & .218 & -.022 \\
\hline & PVC4 & 2.82 & 999 & .675 & & .023 & -.377 \\
\hline & PVC5 & 2.95 & .841 & .656 & & -.052 & -.302 \\
\hline
\end{tabular}




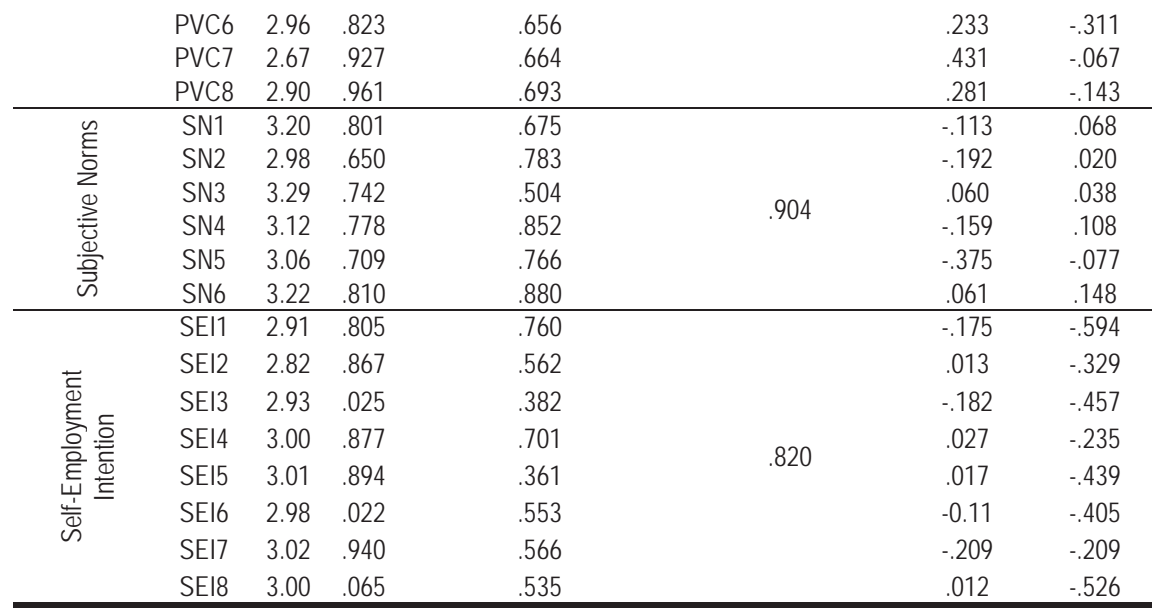

Table 1.2: Exploratory Factor Analysis

\begin{tabular}{|c|c|c|c|c|c|c|}
\hline \multicolumn{7}{|c|}{ Rotated Component Matrix ${ }^{a}$} \\
\hline \multirow[b]{2}{*}{ Items } & & & \multicolumn{4}{|c|}{ Component } \\
\hline & & & & 2 & 3 & 4 \\
\hline \multirow{8}{*}{ 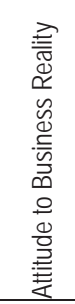 } & ABR1 & I have the ability to identify business opportunity & .702 & & & \\
\hline & ABR2 & I know how to conduct market analysis & .585 & & & \\
\hline & ABR3 & I can formulate business objectives & .679 & & & \\
\hline & ABR4 & I know how to set goals \& action for business & .823 & & & \\
\hline & ABR5 & I can identify sources of funds for business & .590 & & & \\
\hline & ABR6 & How to build business management team & .438 & & & \\
\hline & ABR7 & I can manage and withstand business risk & .655 & & & \\
\hline & ABR8 & To develop, motivate client relationship is ease & .728 & & & \\
\hline \multirow{8}{*}{ 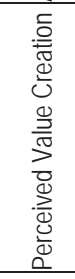 } & PVC1 & Competence to control new business is ease for me & & .622 & & \\
\hline & PVC2 & Am creative to develop new products and services & & .456 & & \\
\hline & PVC3 & Am skilful in creation of business idea & & .533 & & \\
\hline & PVC4 & I have capacity to innovate existing business & & .620 & & \\
\hline & PVC5 & Am confident to do market analysis to new business & & .551 & & \\
\hline & PVC6 & Capacity to use ICT to create business opportunity & & .528 & & \\
\hline & PVC7 & I see REM business risk as opportunity for business idea & & .544 & & \\
\hline & PVC8 & My career goal is to create REM firm or in partnership & & .541 & & \\
\hline \multirow{6}{*}{ 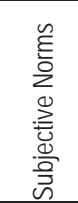 } & SN1 & Your friend & & & .497 & \\
\hline & SN2 & Your parent and family members & & & .488 & \\
\hline & SN3 & Close entrepreneur outside university & & & .575 & \\
\hline & SN4 & Entrepreneur meet in the REM programs & & & .631 & \\
\hline & SN5 & Your entrepreneurship educators & & & .594 & \\
\hline & SN6 & Important people in your community & & & .635 & \\
\hline \multirow{9}{*}{ 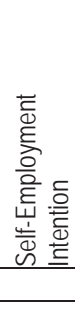 } & SEl1 & Interest to set up my own business & & & & .726 \\
\hline & SEI2 & Am determined to create a firm in future & & & & 611 \\
\hline & SEI3 & Intention to be self-employed one day & & & & .608 \\
\hline & SEI4 & Intention to start business within 2years & & & & .494 \\
\hline & SEI5 & Intention to start business within 5years & & & & .559 \\
\hline & SEI6 & Intention to start business within 10years & & & & 495 \\
\hline & SEI7 & Intention to start business some day & & & & 476 \\
\hline & SEI8 & To be self-employed is my goal in REM & & & & .428 \\
\hline & ractio & $\begin{array}{l}\text { Method: Principal Component Analysis. Rotation Method: } \\
\text { converged in } 11 \text { iterations. }\end{array}$ & & & & \\
\hline
\end{tabular}


Before the CFA and SEM statistical analyses, Awang (2014) emphasized that upon the removal of all the redundant items in the research's constructs, it is important to check their discriminant validity. In the same light, Hair et al. (2011) stated that evaluation of the discriminant validity of the exogenous variables in the research assessment model is vital and that correlation between them should be lower than 0.85 . As shown in Figure 1.1, the discriminant validity of the hypothesized constructs of this research is adequate because the correlation coefficient between the three exogenous constructs is lower than 0.85 .

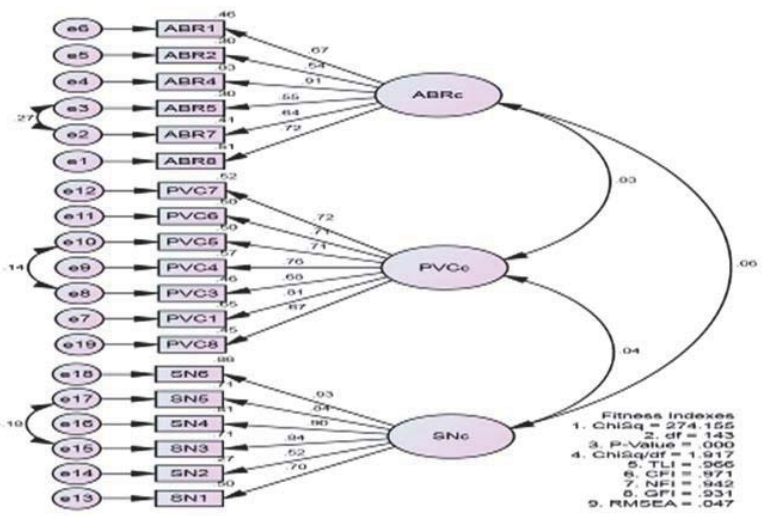

Figure 1.1: Convergent and Discriminant Validity

Figure 1.2 denotes a path diagram that constitutes the determination of the set of interrelationships among the entire research variables that connect our critical construct based on the Theory of Planned Behaviour Model. In this structural equation model, attitude to business reality (ABR), perceived value creation (PVC) and subjective norms (SN) are the three latent variables (factors) that determine or predict the REM students' self-employment intention.

The Figure 1.2 model was tested using the overall sample size from the cross-sectional four Malaysian public universities (UM, UTM, UiTM and UTHM). We tested the Model with the total sample $(n=408)$ as Figure 1.3 (Structural Measurement Model) shows. Therefore, it was observed that chi-square (499.114) presents a p-value (0.000). Awang (2014) and Hair et al. (2011) stated that using structural equation model analysis the chi-square is not as significant as other goodness-of-fitness indices such as chi sq/df, TLI, CFI, NFI, GFI and RMSEA. Here, the incremental fit indices (GFI, TLI, CFI and NFI), absolute fit residual indices (RMR, RMSEA) and parsimonious fit (chisq/df) presented a satisfactory good-fitting model because they fit into acceptable parameters $(\geq 0.90, \leq 0.08$ and $\leq 5.0$ respectively) upon the structural equation modeling analysis. One possible explanation for this result is that the total sample was integrated by all the REM students in the Malaysian public universities and this has an impact on the measures of attitude to business reality, perceived value creation, subjective norms and self-employment intention.

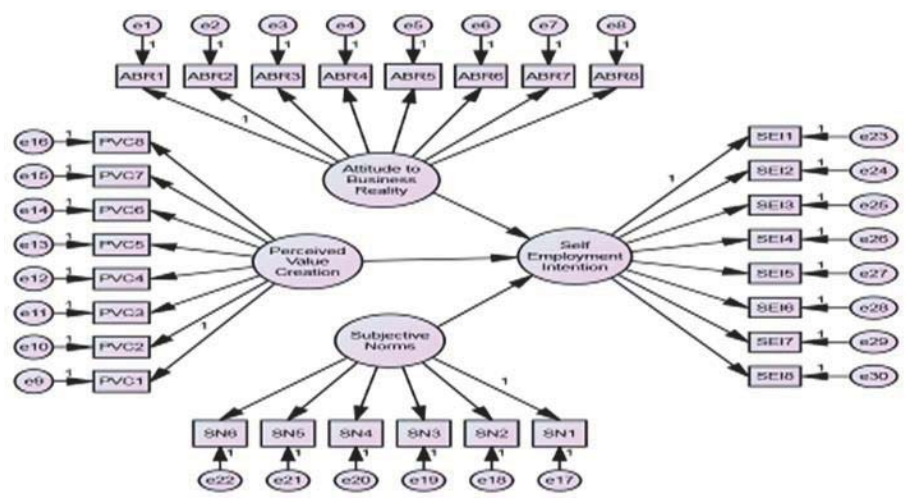

Figure 1.2: Path Diagram of Self-Employment Intention Model 


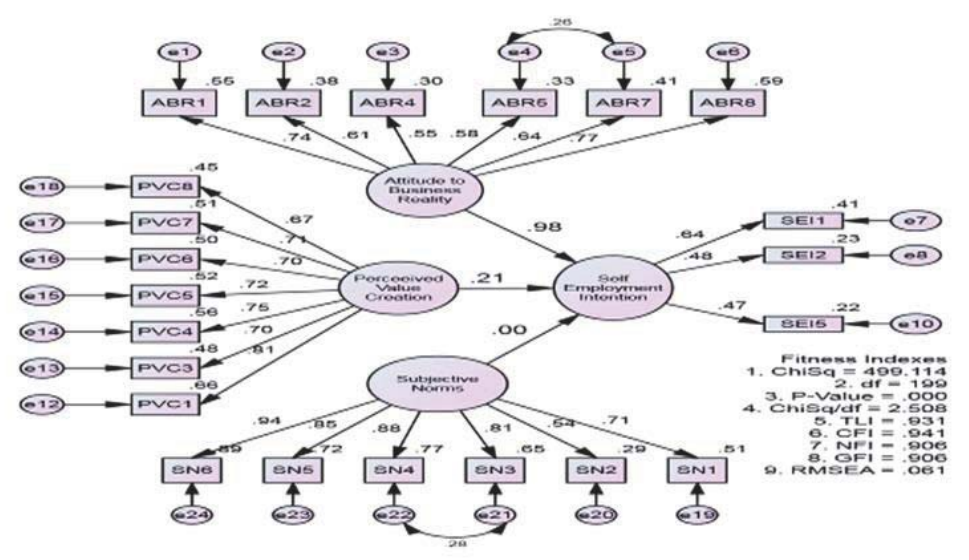

Figure 1.3: Structural Measurement Model with Standardized Regression Coefficient for the Research Path Diagram of Self-Employment Intention Model

Firstly, the model indicates that all the regression weights for these predictions are significantly different from zero at $99 \%$ confidence level. It means that the principal regression weights show that the REM students' attitude to business reality in the prediction of self-employment intention (0.98) is significantly different from zero at the 0.0001 level (two-tailed); in other words, the REM students' self-employment intention to start a new business after graduation is impacted positively and significantly by the attitude to business reality $(\beta=0.977, z=12.031$ and $p=0.000<0.001)$. Therefore, research hypothesis $(\mathrm{H} 1)$ is supported.

Secondly, the model indicates that the regression coefficient weights shows that the REM students' perceived value creation in the determination of self-employment intention (0.21) is significantly different from zero at the 0.0001 level (two-tailed); in other words, the REM students' self-employment intention to start a new business after graduation is impacted positively and significantly by the perceived value creation $(\beta=0.213, z=4.013$ and $p=0.000<0.001)$. Therefore, research $\mathrm{H} 2$ is supported.

On the contrary, the REM students' intention to be self-employed after graduation is impacted negatively and not significantly by the perception of subjective norms $(\beta=-0.001, z=-0.012$ and $p=0.990>0.05)$. Therefore, research $\mathrm{H} 3$ is not supported. Notable empirical findings of the Linan et al. (2011), Kolvereid and Isaksen (2006) and Ismail et al. (2009) reported similar research outcomes.

Furthermore, Table 1.3 presented the regression weights for the overall sample size $(n=408)$. The SEM's result presents that all relationships have a positive impact and are significant at $99 \%$ confidence level, except subjective norms presents no impact and not significant in the context of this research. In the relationship between self-employment intention and the three predictive variables, attitude to business reality has major estimate impact than the others. In another word, the impact of attitude to business reality is highest in REM students.

Table 1.3: The Standardized Regression Weights and Its Significance for the Research Self-Employment Intention Model

\begin{tabular}{|c|c|c|c|c|c|c|c|c|}
\hline $\mathrm{N}=408$ & Construct & Path & Construct & Standardized Estimates & S.E. & C.R. & P-Value & Result \\
\hline \multirow{3}{*}{$\begin{array}{l}\frac{n}{0} \\
\text { 䓌 } \\
\text { 号 }\end{array}$} & SEI & $<--$ & ABR & 0.977 & 0.070 & 12.031 & 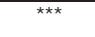 & Significant \\
\hline & SEI & $<--$ & PVC & 0.213 & 0.037 & 4.013 & *** & Significant \\
\hline & SEI & $<--$ & SN & -0.001 & 0.046 & -0.012 & 0.990 & Not Significant \\
\hline
\end{tabular}

Note: ${ }^{* \star *} p<0.0001, \mathrm{ABR}=$ Attitude to Business Reality; PVC = Perceived Value Creation; SN = Subjective Norms and SEI = Self-Employment Intention.

Feasible explanations about these results point out that attitude to business reality and perceived value creation arethe predominant predictors of the Malaysian REM students' self-employment intention. To a large extend, societal factors such as pier friends, family members and entrepreneurship educators do not impact their intention of wanting to be self- 
employed upon graduation. The outcome of this research shows that it is consistent with several studies in the entrepreneurship literature that have established that there is no significant impact or direct relationship between subjective norms and self-employment intention (Fayolle et al., 2006; Kolvereid \& Isaksen, 2006; Ismail et al., 2009).

Therefore, it could be safely concluded that REM students do not believe that perception of the subjective norms could influence their intention toward self-employment or willingness for the creation of new business firm after their graduation, possibly because the REM practice is inherently entrepreneurial in nature according to Poon and Brownlow (2015).

\subsection{Discussion on the Research Findings}

This research attempts to examine how the attitude to business reality, perceived value creation and subjective norms impact REM students' self-employment intention. In this regards, the research findings have been relatively satisfactory in the context of this study sample and data at hand. Two of the exogenous variables (attitude to business reality and perceived value creation do have very positive significant impact on the REM students' self-employment intention, whereas, subjective norms do not. It is not surprising that attitude to business reality (business management acumen) has the strongest impact on other independent variables because REM is a profession with a core background in management, finance and marketing proficiency. In addition, leadership, project management and valuation analytical skills sets in the core educational training of the REM student have strong hold influence on the attitude toward business reality and onward impact on their intention to be self-employed. More so, the educational teaching process (negotiation, networking and marketing) on how to buy and sell landed properties are inherently entrepreneurial both in theory and practice.

The fair achievement of this survey is that it has supported the hypothesized relationships between perceived value creation and self-employment intention $(\mathrm{H} 2)$ which can be explained in at least two different perspectives. First, the direct impact of the perceived value creation over the attitude to business reality is not reflected in this result probably because of weakness perception of the REM students in the key areas of skills of creativity and innovation capacity even though, it has a significant relationship. The positive perception of the value creation capacity of the REM students is a clear indication that it constituted the core determinant of their self-employment intention that is a forerunner in the entrepreneurship development and firm creation. Also, Gafar et al. (2014) and Thompson and Kwong (2014) emphasized that a positive perception of value creation capacity is the degree to which individual holds positive business creation about being an entrepreneur. Since the primary purpose of the entrepreneurship education in the Malaysian HLIs is for the business creation, therefore, there is a need for the most significant impact on this component of intention model. Holistic entrepreneurship education could be a vital mechanism to advance the REM students' positive perceived value creation capacity in the HLIs. This finding may immensely contribute to the entrepreneurship educational policy in general.

With regard to the selected Malaysian public universities for the research empirical analysis, and in accordance with these research outcomes, it could be safely interpreted that despite the government proactive, entrepreneurial initiatives, subjective norms as factors seem not to have any distinct entrepreneurial re-orientation among the majority of the Malaysian students. This could be probably explained by two distinct factors. First, low or no significant influence of close family members and pier friends of the students of HLIs in Malaysia could lead to self-employment not being highly valued as a career option. Second, lack of strong perceived value creation capacities (entrepreneurial skills) among the students could also lead to weaker or negative motivational elements such as perceived behavioral control or self-efficacy towards self-employment and subsequent business firm creation after graduation.

\section{Conclusion}

In the academic community, some commentators have argued that effort toward entrepreneurship teaching in the Malaysian HLIs is not to create entrepreneurial awareness but primarily to develop self-motivated graduates. Entrepreneurship with the primary goal of self-employment is not only about the creation of a job for the potential entrepreneurs, but ultimately for wealth creation and national economic development. However, starting a business and entering into self-employment is in most cases the first step in an entrepreneurial career. To really learn about entrepreneurship, study of success stories is not sufficient, instead, we also need foundational knowledge of how attitude toward business reality, perceived value creation and subjective norms impact self-employment intention that is the process entrepreneurs go through on their way to success or failure.

The present research illustrates that the theory of planned behaviour is well suited for research into self- 
employment intention. The central conclusion drawn from this study relates to a better understanding of the mechanisms through which attitude to business reality, perceived value creation and subjective norms constructs are formed and measured, which in turn determine self-employment intention. Attitude toward business reality explains a substantial fraction of the variance in the of self-employment intention. That is, the impact of attitude toward business reality and perceived value creation shared among the REM students as the predominant predictors of their self-employment intention, not as a result of their family members/pier friends or educators.

On the account of the above, there is a strong case for the enhancement of the creative and innovative skills such as opportunity recognition; idea development; problem solving; creativity and innovation; leadership; communication and; networking. In fact, they are required for successful development of self-employment intention to business/firm creation and the sustenance of the firms. More emphasis on the skills as mentioned earlier in the entrepreneurship education course content with the holistic teaching approach would be a distinct policy action to be taken.

\section{References}

Ajzen, I. (1991). The Theory of Planned Behavior. Organizational Behavior and Human Decision Processes, 50(2), 179-211.

Ajzen, I. (2001). Nature and operation of attitudes. Annual Review of Psychology, 52, 27-58.

Ajzen, I. (2002). Perceived behavioral control, self-efficacy, locus of control and the theory of planned behavior. Journal of Applied Social Psychology, 32(4), 665-683.

Awang, Z. (2014). Research Methodology and Data Analysis. Penerbit Press, UniversitiTeknologi Mara.

Bae, T. J., Qian, S., Miao, C. \& Fiet, J. O. (2014). The Relationship between Entrepreneurship Education and Entrepreneurial Intentions: A Meta-Analytic Review. Entrepreneurship Theory and Practice, 38(2), 217-254.

Blenker, P., Korsgaard, S., Neergaard, H. \& Thrane, C. (2011). The questions we care about: paradigms and progression in entrepreneurship education. Industry and Higher Education, 25(6), 417-427.

Douglas, E. J. \& Shepherd, D. A. (2002). Self-employment as a career choice: attitudes, entrepreneurial intentions, and utility maximization. Entrepreneurship Theory and Practice, 26(3), 81-90.

Ernest, K., Matthew, S. K. \& Samuel, A. K. (2015). Towards Entrepreneurial Learning Competencies: The Perspective of Built Environment Students. Higher Education Studies, 5(1), p20.

Fayolle, A. (2013). Personal views on the future of entrepreneurship education. Entrepreneurship \& Regional Development, 25(7-8), 69 $2-701$.

Fayolle, A., \& Liñán, F. (2014a). The future of research on entrepreneurial intentions. Journal of Business Research, 67(5), 663-666.

Fayolle, A., Gailly, B. \& Lassas-Clerc, N. (2006). Assessing the impact of entrepreneurship education programmes: a new methodology. Journal of European Industrial Training, 30(9), 7001-720.

Fayolle, A., Linan, F. \& Moriano, J. A. (2014b). Beyond entrepreneurial intentions: values and motivations in entrepreneurship. International Entrepreneurship and Management Journal, 10(4), 679-689.

Gafar, M., Kasim, R. \& Martin, D. (2014a). Is the Impact of Entrepreneurship Education as Remarkable as the Demand? Proceeding of International Conference on the Emerging Trends in Scientific Research, 130-144.

Gafar, M., Kasim, R. \& Martin, D. (2013). Entrepreneurial Idea Development to Business Start-Up: Teaching Methodological Approach. Journal of Research \& Method in Education, Vol. 1 (4), PP 46-55.

Gafar, M., Kasim, R. \& Martin, D. (2014b).The Impact of Entrepreneurship Education on the Students' Entrepreneurial Value Creation.Proceeding of International Conference on Global Trends in Academic Research, Bali, Indonesia.

Guerrero, M., Rialp, J. \& Urbano, D. (2008). The impact of desirability and feasibility on entrepreneurial intentions: A structural equation model. International Entrepreneurship and Management Journal, 4(1), 35-50.

Hair, J. F. (2011). Multivariate Data Analysis: A Global Perspective. Saddle River: Prentice Hall

Ismail, M., Khalid, S. A., Othman, M., Jusoff, H. K., Rahman, N. A., Kassim, K. M. \& Zain, R. S. (2009). Entrepreneurial intention among Malaysian undergraduates. International Journal of Business and Management, 4(10), p54.

Kolvereid, L. \& Isaksen, E. (2006). New business start-up and subsequent entry into self-employment. Journal of Business Venturing, 21(6), 866-885.

Kolvereid, L. (1996a). Organizational Employment Versus Self-Employment: Reasons for Career Choice Intentions. Entrepreneurship: Theory \& Practice, 20(3): 23- 31.

Krueger Jr, N. F., Reilly, M. D. \& Carsrud, A. L. (2000).Competing models of entrepreneurial intentions.Journal of business venturing, 15(5), 411-432.

Krueger, N. (2009). Entrepreneurial intentions are dead: Long live entrepreneurial intentions. In Understanding the entrepreneurial mind (pp. 51-72). Springer New York.

Linan, F. \& Chen, Y. W. (2009). Development and Cross-Cultural application of a specific instrument to measure entrepreneurial intentions. Entrepreneurship Theory and Practice, 33(3), 593-617.

Linan, F. \& Fayolle, A. (2015). A systematic literature review on entrepreneurial intentions: citation, thematic analyses, and research agenda. International Entrepreneurship and Management Journal, 1-27.

Linan, F., Rodríguez-Cohard, J. C. \& Rueda-Cantuche, J. M. (2011). Factors affecting entrepreneurial intention levels: a role for education. International Entrepreneurship and Management Journal, 7(2), 195-218. 
Matlay, H. (2008). The impact of entrepreneurship education on entrepreneurial outcomes. Journal of Small Business and Enterprise Development, 15(2), 382-392.

Nabi, G., Holden, R. \& Walmsley, A. (2006). Graduate career-making and business start-up: a literature review. Education + Training, 48(5), 373-385.

Pallant, J. (2011). SPSS Survival Manual 4th edition: A step by step guide to data analysis using SPSS version 18. Crows Nest. New South Wales: Allen \& Unwin.

Peterman, N. E. \& Kennedy, J. (2003). Enterprise Education: Influencing students' perceptions of entrepreneurship. Entrepreneurship theory and practice, 28(2), 129-144.

Poon, J. \& Brownlow, M. (2015). Development of students' commercial awareness within the curriculum of professionally accredited courses: a case study of property courses. Education+ Training, 57(4).

Poon, J. (2012). Real estate graduates' employability skills: The perspective of human resource managers of surveying firms. Property Management, 30(5), 416-434.

Poon, J. (2013a). An examination of a blended learning approach in the teaching of economics to property and construction students. Property Management, 31(1), 39-54.

Shapero, A. \& Sokol, L. (1982). The social dimension of entrepreneurship, in Kent, C., Sexton, D., and Vesper, K., Edition. The encyclopedia of Entrepreneurship, Prentice-Hall, Englewood Cliffs, NJ, pp. 72-90.

Souitaris, V., Zerbinati, S. \& Al-Laham, A. (2007). Do entrepreneurship programmes raise entrepreneurial intention of science and engineering students? The effect of learning, inspiration and resources. Journal of Business Venturing, 22(4), 566-591.

Thompson, P. \& Kwong, C. (2014). Compulsory School Based Enterprise Education as a Gateway to an Entrepreneurial Career. Retrieved from http://isbe.org.uk/content/assets/Enterprise_Education-_Caleb_Kwong, 1-20.

Tkashev \& Kolvereid (1999). Self-employment intentions among Russian students. Entrepreneurship and Regional Development 11 (3), $269-280$.

Van Gelderen, M., Brand, M., van Praag, M., Bodewes, W., Poutsma, E. \& Van Gils, A. (2008). Explaining entrepreneurial intentions by means of the theory of planned behaviour. Career Development International, 13(6), 538-559.

Wilson, F., Kickul, J. \& Marlino, D. (2007). Gender, Entrepreneurial Self-Efficacy, and entrepreneurial career intentions: Implications for Entrepreneurship Education1. Entrepreneurship theory and practice, 31(3), 387-406.

Zamberi Ahmad, S., Roland Xavier, S. \& Rahim Abu Bakar, A. (2014). Examining entrepreneurial intention through cognitive approach using Malaysia GEM data. Journal of Organizational Change Management, 27(3), 449-464.

Zhao, H., Seibert, S. E. \& Hills, G. E. (2005). The mediating role of self-efficacy in the development of entrepreneurial intentions.Journal of applied psychology, 90(6), 1265. 